\title{
Clinical Study Document Relationship Type
}

National Cancer Institute

\section{Source}

National Cancer Institute. Clinical Study Document Relationship Type. NCI Thesaurus.

Code C71107.

A particular category of the relationship between two items of study-related documentation. 